\title{
The impact of the soil sealing degree on microbial biomass, enzymatic activity, and physicochemical properties in the Ekranic Technosols of Toruń (Poland)
}

\author{
Anna Piotrowska-Długosz • Przemysław Charzyński
}

Received: 14 February 2014 / Accepted: 5 August 2014 / Published online: 23 August 2014

(C) The Author(s) 2014. This article is published with open access at Springerlink.com

\begin{abstract}
Purpose Artificial soil sealing in urban areas has attracted increasing attention because of its potential hazard to urban ecosystem. Covering soils with impervious materials has a significant impact on their properties and is essentially an irreversible process. In contrast to natural, open soils, sealed soils undergo a significant alteration of their physicochemical properties, and in turn, negatively influence microbial biomass and enzymatic activity.

Materials and methods In general, 33 soils from different parts of the city of Torun (NW Poland) were sampled and divided into 3 groups according to the degree of soil sealing: (1) soils sealed with semi-pervious concrete paving slabs (A), (2) soils sealed with impervious surfaces, such as asphalt and concrete (B), and (3) non-sealed soils (the reference groupC). Soil samples were assayed for (1) microbial biomass carbon $(\mathrm{MBC})$, and nitrogen $(\mathrm{MBN})$ and soil respiration activity (RESP), (2) the activity of soil enzymes, and (3) physicochemical properties.

Results and discussion Soil sealing significantly reduced the content of carbon and nitrogen (both total and microbial), soil respiration, the activity of urease, and fluorescein diacetate hydrolysis compared to non-sealed soils (C), while the degree of soil sealing did not significantly affect these properties. Soil moisture and nitrate reductase activity were the only
\end{abstract}

Responsible editor: Stefan Norra

A. Piotrowska-Długosz

Department of Soil Science and Soil Protection, Division of Biochemistry, Faculty of Agriculture and Biotechnology, University of Technology and Life Sciences, 6 Bernardyńska St.,

85-029 Bydgoszcz, Poland

P. Charzyński $(\bowtie)$

Department of Soil Science and Landscape Management, Faculty of

Earth Sciences, Nicolaus Copernicus University Torun, 187

Lwowska St., 87-100 Toruń, Poland

e-mail: pecha@umk.pl properties significantly differentiated by the degree of soil sealing. Canonical correlation analysis indicated that soil biological activity was caused mainly by the variation in MBC and MBN content, as well as dehydrogenase, catalase, and cellulase activities. The highest correlation was obtained between the soil moisture and the first canonical variable for microbial biomass and enzymatic activity.

Conclusions The results showed that the artificial sealing in urban areas can significantly alter the soils by reducing their carbon and nitrogen content as well as microbial biomass and its activity compared with open soils. The analysis of variance showed that the degree of soil sealing did not affect most of the studied soil properties, although the differences in raw data between impervious and semi-pervious sites were remarkable.

Keywords Ekranic Technosols · Enzyme activities · Impervious sites $\cdot$ Microbial biomass $\cdot$ Semi-pervious sites $\cdot$ Soil sealing

\section{Introduction}

Most of the previous studies in soil science have focused mainly on agricultural and forest soils, but now there is much stronger interest in urban soils because of the growing urban population (Lorenz and Kandeler 2005). According to the European Environment Agency (EEA 2006), the total surface area of cities in the EU has increased since the mid 1950s by $78 \%$, whereas the population has increased by only $33 \%$. Urban soils are extensively altered by human activities like sealing, compaction, landfilling, and mixing (Wei et al. 2013). Soil sealing may involve total imperviousness, as caused by concrete or asphalt, or soil may be sealed with semi-pervious surface such as concrete paving slabs, which allow partial penetration of water and air (Nestroy 2006). Sealing of soils, erosion, reduction of organic matter, local and diffused 
pollution, soil compactness, and salinity are the main causes of soil degradation in the European Union (EU). Thus, the increase in impervious areas can be considered as a suitable indicator of land degradation (Salvati et al. 2011). Soil sealing has a significant impact on the functioning of soil, causing an irreversible loss of its biological functions and loss of biodiversity through landscape fragmentation. Soil sealing often affects fertile agricultural lands, increases the risk of flooding and water deficiency, and contributes to global warming (Couch et al. 2007; Scalenghe and Ajmone Marsan 2009; Technical Report 2011). Most previous studies have focused on effects of sealed areas on water movement (Bhaduri et al. 2001; Peffy and Nawaz 2008), gas diffusion (Wiegand and Schott 1999; Kaye et al. 2004), and biodiversity (Savard et al. 2000), while effects of soil sealing on nutrient cycling and biological components, such as soil microorganisms diversity and enzymatic activity, were seldom investigated (Zhao et al. 2012; Wei et al. 2013). The sealing of soils prevents the exchange of gases, water, and nutrients between the soil and the atmosphere, which results in a negative effect on their physicochemical properties (Zhao et al. 2012). This, in turn, could negatively influence the microbial and enzymatic activity, since microorganisms are the main source of enzymes in soils.

It has been suggested that soil microbiological and biochemical properties can be useful indicators of variation in soil functions and activity as influenced by natural and anthropogenic factors (Gianfreda and Ruggiero 2006). The soil microbial biomass, which is the living part of the soil organic matter, functions as a transient nutrient sink and is responsible for the decomposition and transformation of organic matter (Ananyeva et al. 1999). Soil enzymes, secreted mainly by soil microorganisms, reflected the dynamics of microbial metabolic processes associated with the conversion of organic compounds and nutrient cycling and were sensitive indicators of environmental stress due to decreasing soil quality (Wang et al. 2011).

In the last years, the interest of soil sealing assessment through effective monitoring has been rapidly growing in Europe (EEA 2006, 2010). In the context of the Soil Thematic Strategy (EC 2006), the European Commission points out the need to develop the best practices aimed at mitigating the negative effects of sealing on the soil functions. In 2011, the European Commission published a report presenting the land use and soil sealing trends in the EU (Technical report 2011). The report contains a comprehensive overview of the existing Member State policies and technical measures used to reduce and mitigate the soil sealing.

So far, the problems of urban sprawl and soil sealing in Poland are not exactly monitored and relatively little recognized. On the other hand, Ekranic Technosols of Torun have been already researched. The largest homogeneous area of such soils in the city is located under the runway and taxiways of Toruń Aerodrome (Charzyński et al. 2013a). Ekranic Technosols of the city center area were also described (Charzyński et al. 2011, 2013b). In the key document for spatial planning for the period of 2008 to 2033 (Technical Report 2011), the reduction of urban sprawl and soil sealing in Poland is not listed as a propriety issue and they are not fully recognized in the policy preparation guidelines. Between 2005 and 2012, the size of built-up and urbanized areas increased by $7.2 \%$, whereas no population growth was observed (Statistical Yearbook of Agriculture 2011). The size of sealed surface in Poland is about $12 \%$ smaller than the EU average. So far, soil sealing and urban sprawl are not a major problem in Poland. For the next decade, however, a considerable increase in the annual soil sealing can be expected due to the planned expansion of road networks and the resulting private transport since an increase of 6 million vehicles is expected by 2020 (Technical Report 2011).

As stated earlier (Burghardt 2006; Wessolek 2008; Technical Report 2011), soils under sealed surfaces are still important since they support the growth of roadside trees and allow the infiltration of stormwater. Therefore, the investigation and evaluation of properties of these soils is important to soil protection, management, and restoration (Karlen et al. 2003). Consequently, the aim of this study was to compare the biological (soil microbial biomass and enzyme activities) and physicochemical properties of Ekranic Technosols from Torun, Poland, and adjacent, non-sealed soils. We hypothesized that (1) soil physicochemical and biological properties would significantly deteriorate over a 30 -year-long soil sealing compared to non-sealed soils, and (2) the degree of soil sealing would significantly differentiate the data of soil properties.

\section{Material and methods}

\subsection{Description of the study area and soil sampling}

The study sites were located in the urban area of Torun $\left(18.609^{\circ} \mathrm{E}, 53.020^{\circ} \mathrm{N}\right)$, NW Poland. Soils in the studied area are defined mostly as medium sand according to USDA Soil Taxonomy (Soil Survey Staff 2010). Some soils belong to textural classes of coarse and fine sand. The climate of the region is moderate of a transitional type between the marine type of Western Europe and the continental type of Eastern Europe. The average annual temperature in 2011 was 9.4 and $9.1{ }^{\circ} \mathrm{C}$ in 2012 , while the annual rainfall was $462.8 \mathrm{~mm}$ in 2011 and $500.7 \mathrm{~mm}$ in 2012. The mean air temperature and sum of precipitation in Torun at the time of soil sampling are presented in Table 1 (http://www.tutiempo.net/en/Climate/ Poland/PL.html).

In general, 33 soils from 7 parts of the city were sampled between April and September 2012 (Fig. 1). In each place, soils under impenetrable surface, semi-permeable surface, and 
Table 1 Mean air temperature and sum of precipitation in Torun in 2012

\begin{tabular}{lll}
\hline Month & Temperature $\left({ }^{\circ} \mathrm{C}\right)$ & Precipitation $(\mathrm{mm})$ \\
\hline April & 9.2 & 33.0 \\
May & 15.0 & 24.9 \\
June & 15.8 & 96.0 \\
July & 19.3 & 85.4 \\
August & 18.6 & 28.4 \\
September & 14.0 & 45.0 \\
\hline
\end{tabular}

Source: http://www.tutiempo.net/en/Climate/Poland/PL.html

Data reported by the weather station: 122500

non-sealed soils were selected. They were situated close to each other to have the same soil texture and environment conditions (Fig. 1). Samples from sealed soils were collected for laboratory analysis from topmost horizons that survived the process of pavement construction. It was collected by horizontal soil borehole drilling from a depth of $15-25$ or 10-20 cm, depending on the thickness of the technic hard rock, together with the ballast layer (laying course) used for stabilization of the pavement construction. Usually, it was the upper part of the $\mathrm{B}$ horizon or remains of the $\mathrm{AB}$ horizon. Reference sites were located in the direct proximity (about $1 \mathrm{~m}$ ) of sidewalks to ensure maximum soil similarity. Samples were collected from the same depth as in the sealed soils (Fig. 2). The age of sealing at the impervious sites ranged between 30 and 40 years. The studied pedons were divided into 3 groups as follows: (1) soils sealed with concrete paving slabs, which allow partial penetration of water and air, with 9 samples collected (group A); (2) soils sealed with impervious surfaces, such as asphalt and concrete, where 11 samples were collected (group B); and (3) non-sealed soils situated in adjacent areas where 13 samples were collected (group C). Examples of sealed soils-Ekranic Technosols according to WRB (IUSS Working Group WRB 2014) are shown in Fig. 3.

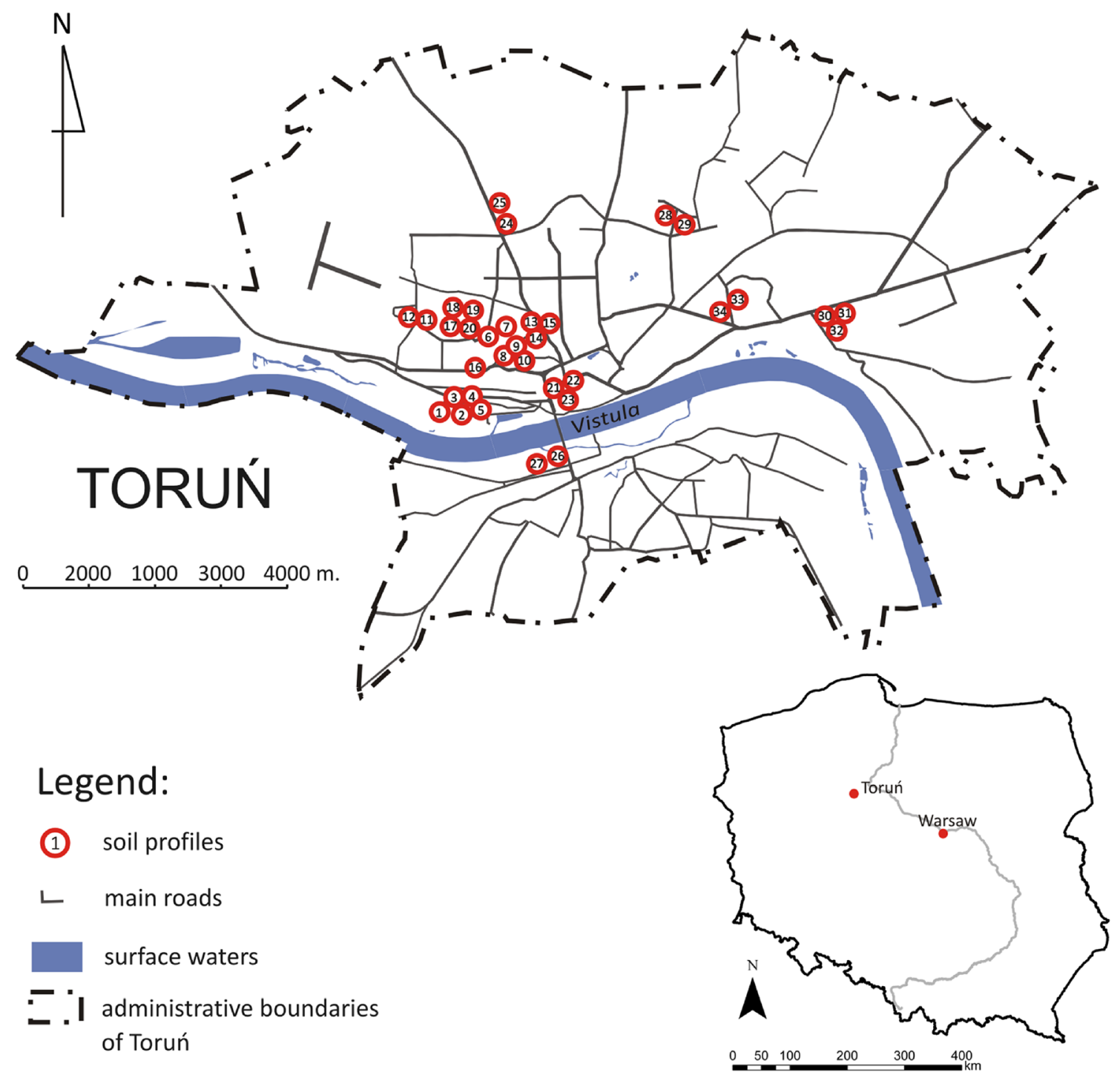

Fig. 1 Location of the study sites 
Fig. 2 Soil sampling scheme

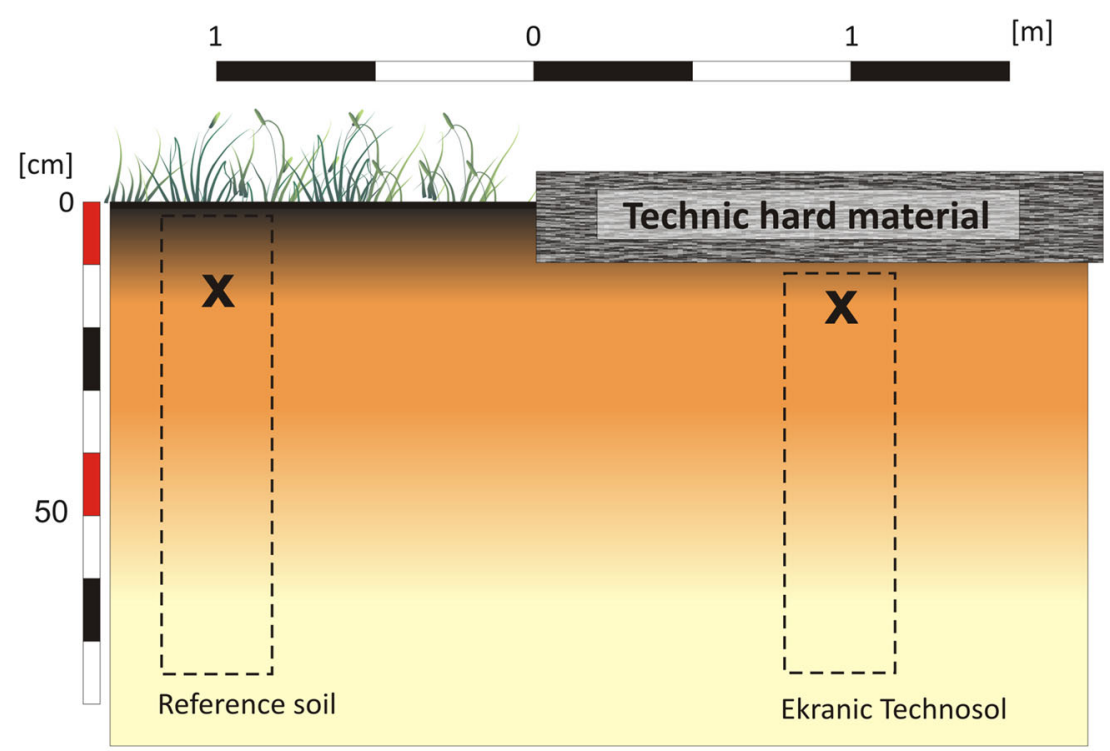

\section{X - soil sampling}

Field-moist samples were sieved $(<2 \mathrm{~mm})$ and stored at $4{ }^{\circ} \mathrm{C}$ in a plastic box for not less than 2 days in order to stabilize the microbial activity and then were analyzed for biological properties within 2 weeks. After air-drying at room
Fig. 3 Examples of Ekranic Technosols with semi-pervious surface: (1) site no. 1, (2) site no. $8,(3)$ site no. 26 ; with impervious surface: (4) site no. 10, (5) site no. $16,(6)$ site no. 32
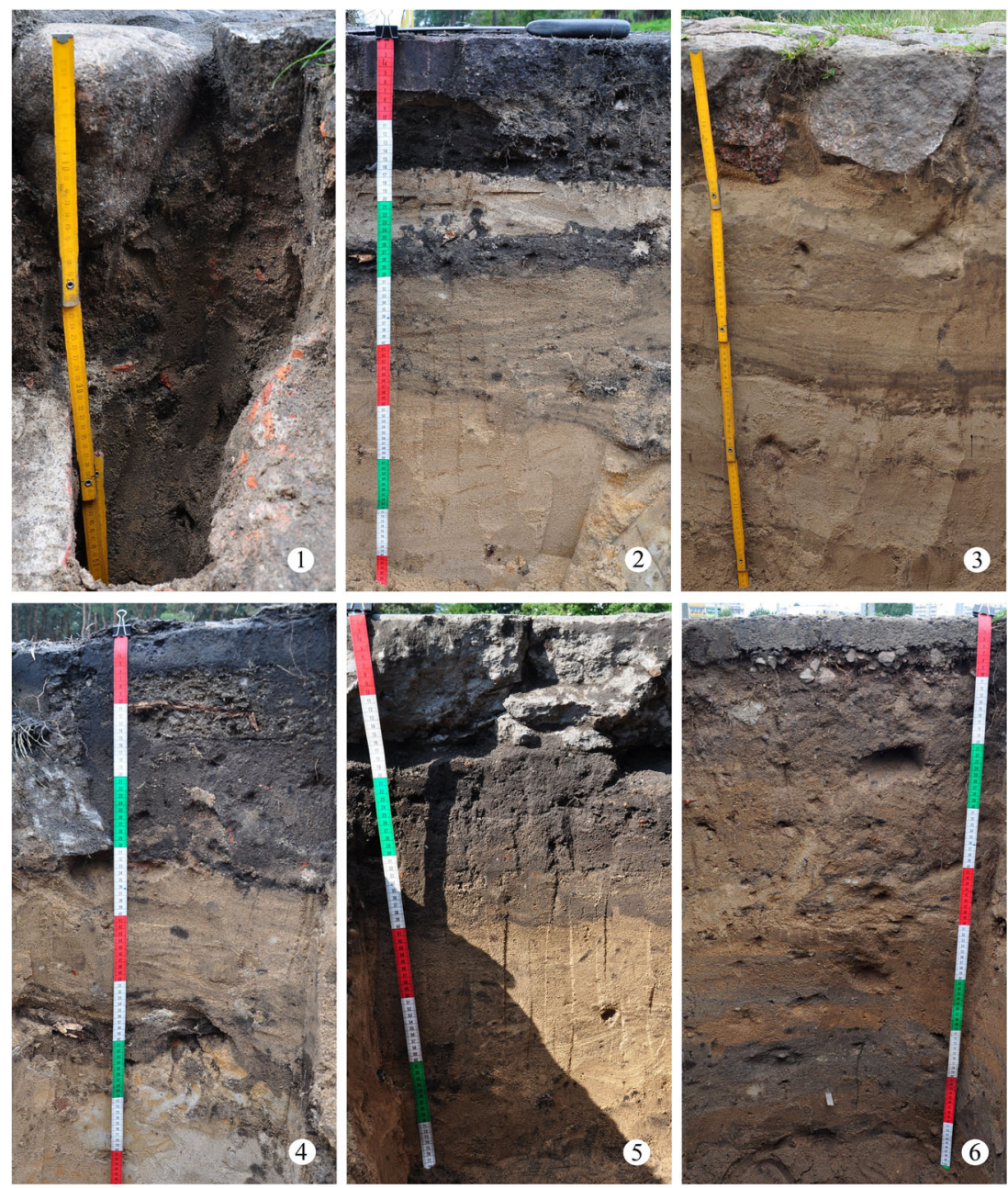
temperature and sieving $(<2 \mathrm{~mm})$, the soil samples were analyzed for physical and chemical properties.

\subsection{Microbial biomass content and respiration rate}

Basal respiration was determined after $3,6,11,18$, and 28 days during a 28-day-long incubation according to Piotrowska et al. (2006). Briefly, moist soil samples ( $25 \mathrm{~g} \mathrm{dw})$ were incubated at $25^{\circ} \mathrm{C}$ and $\mathrm{CO}_{2}$, which evolved over the required time, was trapped in a $0.05 \mathrm{M} \mathrm{NaOH}$ solution and residual $\mathrm{NaOH}$ was titrated with $0.05 \mathrm{M} \mathrm{HCl}$. All samples were corrected for the $\mathrm{CO}_{2}$ content of blanks. The metabolic quotient $\left(q \mathrm{CO}_{2}\right)$ was calculated from the basal respiration rate and the amount of microbial biomass $\mathrm{C}$ according to the formula of Anderson and Domsch (1990).

Soil microbial biomass C (MBC) and N (MBN) was determined using the chloroform fumigation-extraction method (Brookes et al. 1985; Vance et al. 1987). Three replicates of moist soil samples ( $25 \mathrm{~g} \mathrm{dw}$ ) were fumigated with alcohol-free $\mathrm{CHCl}_{3}$ for $24 \mathrm{~h}$ at $25^{\circ} \mathrm{C}$. After removal of the fumigant, the soil samples were extracted with $0.5 \mathrm{~mol} \mathrm{l}^{-1} \mathrm{~K}_{2} \mathrm{SO}_{4}$ for $30 \mathrm{~min}$ and then filtrated. The non-fumigated soils samples were processed similarly for the determination of the background level. The filtrates were frozen at $-20{ }^{\circ} \mathrm{C}$ for the analysis of extractable C (Vance et al. 1987) and N (Bremner and Mulvaney 1982). Soil MBC and MBN were calculated as a difference between fumigated and non-fumigated samples, and $K_{\mathrm{EC}}=0.45$ for $\mathrm{N}$ (Vance et al. 1987) and $K_{\mathrm{EN}}=0.54$ for $\mathrm{C}$ (Brookes et al. 1985) were used to indicate the extraction efficiency.

Additionally, soil microbial parameters, such as microbial$\mathrm{C}$ to $\mathrm{C}_{\mathrm{ORG}}$ (MBC: $\mathrm{C}_{\mathrm{ORG}}$ ), microbial biomass- $\mathrm{N}$ to $\mathrm{N}_{\mathrm{TOT}}$ (MBN: $\mathrm{N}_{\mathrm{TOT}}$ ), or basal respiration to microbial biomass (metabolic quotient, $q \mathrm{CO}_{2}$ ), were calculated to describe changes in the soil environment.

\subsection{Soil enzyme activity}

Dehydrogenase (DHA) activity was determined according to the method described by Thalmann (1968) using triphenyltetrazolium chloride (TTC, $3 \mathrm{mg} \mathrm{ml}^{-1}$ ) as a substrate. Catalase activity was assayed according to Johnson and Temple (1964) with $0.3 \%$ hydrogen peroxide solution as a substrate. The residual $\mathrm{H}_{2} \mathrm{O}_{2}$ was determined by titration with $0.02 \mathrm{M} \mathrm{KMnO}_{4}$. $\beta$-glucosidase activity (GLU) was measured as described by Eivazi and Tabatabai (1988) using $p$-nitrophenol-B-glucoside as a substrate incubated with $4 \mathrm{ml}$ of buffer (MUB, pH 6.0). The global soil hydrolysis activity was evaluated by measuring the activity of fluorescein diacetate hydrolysis (FDA) as described by Adam and Duncan (2001) with phosphate buffer $(60 \mathrm{mM}, \mathrm{pH} 7.6)$ and fluorescein diacetate $(10 \mu \mathrm{g} / \mathrm{ml})$ as a substrate. Soil urease activity (UR) was assayed as described by Kandeler and Gerber (1988). The method is based on the determination of ammonia released after the incubation of soil samples with borate buffer $(\mathrm{pH}$ 10.0) and urea solution for $2 \mathrm{~h}$ at $37^{\circ} \mathrm{C}$. Nitrate reductase activity (NR) was determined according to Kandeler (1995) with $25 \mathrm{mM} \mathrm{KNO}_{3}$ as a substrate. According to the method of Schinner and von Mersi (1990), cellulase activity (CEL) was assayed by incubation of soil samples with water-soluble carboxymethylcellulose $\left(\mathrm{CMC}, 7 \mathrm{mg} \mathrm{ml}^{-1}\right.$ ) for $24 \mathrm{~h}$ at $50{ }^{\circ} \mathrm{C}$ with acetate buffer (2 M, pH 5.5).

The same procedure, as for the enzyme assay, was followed for the controls but the substrate was added to soil after incubation and immediately before stopping the reaction. All enzyme activity data were calculated on the basis of the ovendry $\left(105^{\circ} \mathrm{C}\right)$ weight of soil.

\subsection{Soil physical and chemical analysis}

Physicochemical properties were determined using standard methods (Burt 2004) and each sample was analyzed in triplicate. The particle size was defined by the areometer method combined with the sieve method. The $\mathrm{pH}$ in $1 \mathrm{~mol} \mathrm{l}^{-1} \mathrm{KCl}$ was measured using the potentiometric method in 1:2.5 soil to solution suspensions; total organic carbon $\left(\mathrm{C}_{\mathrm{ORG}}\right)$ and total nitrogen $\left(\mathrm{N}_{\mathrm{TOT}}\right)$ content was determined using a dry combustion $\mathrm{CN}$ analyzer (Vario Max $\mathrm{CN}$ ). Available phosphorus (P) was assayed using the vanadium-molybdenum method. The bulk density was determined with the method of volume cylinders $\left(100 \mathrm{~cm}^{3}\right)$.

\subsection{Statistical data evaluation}

Data were evaluated using classical statistical methods (STATISTICA v. 9.0 Software) for calculating the mean, maximum and minimum, standard deviation, and the coefficient of variation. Since data of some properties (CAT and CEL activities, the content of $\mathrm{MBC}, \mathrm{MBN}, \mathrm{C}_{\mathrm{ORG}}, \mathrm{N}_{\mathrm{TOT}}$, silt, and soil moisture) did not show a normal distribution according to the Shapiro-Wilk test (Statistica v. 9.0), they were log-transformed. Since the transformation improved the normality of data distribution, further analyses were performed with the corrected data. Differences in the studied properties between soils representing different sealing categories were tested by one-way analysis of variance (ANOVA). Data were analyzed using Tukey's test $(p<0.05)$ to evaluate significant differences between the results obtained in the studied groups of soils $(\mathrm{C}$, non-sealed soils; A, semi-impervious sites; and $\mathrm{B}$, impervious sites). A classification scheme was used to identify the extent of variability in soil properties based on their CV [\%] values where values of 0 $15,16-35$, and $>36 \%$ indicate little, moderate, and high variability, respectively (Wilding 1985).

Canonical correlation analysis was performed on the whole data set to further investigate the dependent relationship between soil microbial and enzymatic activity as well as physicochemical properties. The linear function of the canonical 
variables for microbial biomass and enzyme activities $(M E)$, and soil physicochemical properties $(P C)$, was expressed as below: $M E=a_{1} X_{1}+a_{2} X_{2}+\ldots a_{\mathrm{p}} X_{\mathrm{p}} ; \mathrm{PC}=b_{1} Y_{1}+b_{2} Y_{2}+\ldots b_{\mathrm{p}} Y_{\mathrm{p}}$ where $a_{1}, a_{2} \ldots, a_{\mathrm{p}}(p=10), b_{1}, b_{2} \ldots, b_{\mathrm{q}}(q=9)$ are the undetermined coefficients, and there were maximum correlation coefficient between $M E$ and $P C$.

The relationship between water content and weather condition parameters were estimated using correlation analysis based on Pearson's correlation coefficients $(p<0.05)$. Linear regression analysis was performed in order to examine the possible relationship between the soil water content and soil biological properties.

Cluster analysis was applied to the standardized data to investigated similarities between different properties using a defined metric such as the Euclidean distance (Berrueta et al. 2007). Hierarchical clustering was applied in the most common approach where clusters are built sequentially. The most similar objects are grouped first, and these initial groups are merged according to their similarities. In the single linkage method, the distances or similarities between the two clusters $\mathrm{A}$ and $\mathrm{B}$ are defined as the minimum distance between point $\mathrm{A}$ and point B (Richard and Dean 2002). The results of the clustering procedure were displayed using a tree diagram (dendrogram) for the whole data set since the diagrams for each soil group $(\mathrm{C}, \mathrm{A}$, and $\mathrm{B})$ were similar.

\section{Results}

\subsection{Soil microbial biomass and enzymatic activity}

The content of soil MBC and MBC, as well as RESP within 11 days of incubation, was significantly higher in the control soil compared with sealed soil, while the degree of soil sealing did not influence this property essentially (Tukey's test; $p<0.05$, Table 2; Fig. 4). SD and CV values of the above properties indicated their high dispersion both among and within each group of soils. The coefficients of MBC and MBC variation ranged from 22.9 to $50.2 \%$, which indicated medium and high variability of the data. The release of $\mathrm{CO}_{2}$ was the highest in the first 3 days of incubation and decreased systematically throughout the incubation period (Fig. 4). In the first 11 days of incubation, soil respiration was significantly higher in the control samples (C) as compared with the sealed soils (A and B) and, after this period, the significant differences between the soils being studied disappeared. The ratio of $\mathrm{MBC}$ to $\mathrm{MBN}$ ranged from 3.25 to 5.30. On average, approximately $1.79-3.32 \%$ of the total $\mathrm{C}$ and $3.44-5.88 \%$ of the total $\mathrm{N}$ was bound in the microbial biomass (MBC: $\mathrm{C}_{\mathrm{ORG}}$ and $\mathrm{MBN}: \mathrm{N}_{\mathrm{TOT}}$, respectively). The metabolic quotient was significantly higher in impervious soils (B) as compared with control and semi-pervious sites (C and A; Table 3).
Table 2 Microbial biomass content and enzymatic activity as dependent on the degree of soil sealing

\begin{tabular}{|c|c|c|c|c|}
\hline Variable & $\begin{array}{l}\text { Degree of } \\
\text { soil sealing }\end{array}$ & Mean $( \pm \mathrm{SD})$ & Range & $\mathrm{CV}(\%)$ \\
\hline \multirow[t]{3}{*}{ DHA } & $\mathrm{C}$ & $7.15(8.11) \mathrm{a}$ & $0.90-25.4$ & 113.4 \\
\hline & A & 5.59 (7.98) a & $0.66-24.7$ & 142.8 \\
\hline & B & $4.08(5.29) \mathrm{a}$ & $0.44-18.5$ & 129.6 \\
\hline \multirow[t]{3}{*}{ CAT } & $\mathrm{C}$ & $1.17(1.15) \mathrm{a}$ & $0.065-3.13$ & 97.8 \\
\hline & A & $0.84(0.77) \mathrm{a}$ & $0.23-2.44$ & 91.1 \\
\hline & B & $0.77(0.52) \mathrm{a}$ & $0.23-1.98$ & 67.3 \\
\hline \multirow[t]{3}{*}{ GLU } & $\mathrm{C}$ & $0.13(0.10) \mathrm{a}$ & $0.02-0.30$ & 81.5 \\
\hline & A & $0.10(0.08) \mathrm{a}$ & $0.02-0.21$ & 81.1 \\
\hline & B & $0.08(0.07) \mathrm{a}$ & $0.015-0.21$ & 92.1 \\
\hline \multirow[t]{3}{*}{ CEL } & $\mathrm{C}$ & $4.08(3.44) \mathrm{a}$ & $0.24-10.0$ & 84.4 \\
\hline & A & $5.18(7.02) \mathrm{a}$ & $0.07-18.9$ & 135.6 \\
\hline & B & $2.87(3.50) \mathrm{a}$ & $0.23-11.4$ & 121.0 \\
\hline \multirow[t]{3}{*}{ NR } & $\mathrm{C}$ & $2.79(0.53) \mathrm{a}$ & $1.98-3.99$ & 22.6 \\
\hline & A & $2.52(0.61) \mathrm{a}$ & $1.85-3.85$ & 27.8 \\
\hline & B & $1.81(0.30) b$ & $1.29-2.15$ & 16.5 \\
\hline \multirow[t]{3}{*}{ UR } & $\mathrm{C}$ & $4.25(1.15) \mathrm{a}$ & $2.01-6.54$ & 33.8 \\
\hline & A & $2.73(0.66) b$ & $1.85-3.98$ & 29.3 \\
\hline & $\mathrm{B}$ & $1.97(0.42) b$ & $1.12-2.85$ & 26.2 \\
\hline \multirow[t]{3}{*}{ FDA } & $\mathrm{C}$ & $21.6(8.6) \mathrm{a}$ & $12.9-35.8$ & 43.0 \\
\hline & A & $22.9(9.1) \mathrm{a}$ & $15.3-59.5$ & 50.0 \\
\hline & $\mathrm{B}$ & $13.7(3.7) b$ & $8.6-21.0$ & 38.0 \\
\hline \multirow[t]{3}{*}{ MBC } & $\mathrm{C}$ & $63.8(27.4) \mathrm{a}$ & $34.7-111.2$ & 49.0 \\
\hline & A & $36.9(14.6) b$ & $23.5-66.7$ & 38.5 \\
\hline & B & $32.0(9.72) b$ & $26.0-48.4$ & 22.9 \\
\hline \multirow[t]{3}{*}{$\mathrm{MBN}$} & $\mathrm{C}$ & $15.3(8.0) \mathrm{a}$ & $6.15-29.5$ & 50.2 \\
\hline & A & $9.10(4.0) \mathrm{b}$ & $3.20-17.2$ & 44.5 \\
\hline & B & $6.75(2.2) b$ & $4.12-11.7$ & 29.9 \\
\hline
\end{tabular}

$C$ control (non-sealed soils), $A$ semi-pervious sites, $B$ impervious sites, DHA dehydrogenase activity (mg TPF $\mathrm{kg}^{-1} 24 \mathrm{~h}^{-1}$ ), CAT catalase activity $\left(\mathrm{mM} \mathrm{H}_{2} \mathrm{O}_{2} \mathrm{~kg}^{-1} \mathrm{~h}^{-1}\right), G L U \beta$-glucosidase activity (mg pNP kg $\left.\mathrm{kg}^{-1}\right), C E L$ cellulase activity, $N R$ nitrate reductase activity $\left(\mathrm{mg} \mathrm{N}-\mathrm{NO}_{2}{ }^{-} \mathrm{kg}^{-1} 24 \mathrm{~h}^{-1}\right), U R$ urease activity $\left(\mathrm{mg} \mathrm{N}-\mathrm{NH}_{4}{ }^{+} \mathrm{kg}^{-1} \mathrm{~h}^{-1}\right)$, FDA fluorescein diacetate hydrolysis (mg of fluorescein $\mathrm{kg}^{-1} \mathrm{~h}^{-1}$ ), $M B C$ microbial biomass carbon $\left(\mathrm{mg} \mathrm{kg}^{-1}\right), M B N$ microbial biomass nitrogen $\left(\mathrm{mg} \mathrm{kg}^{-1}\right)$; standard deviation is given in parentheses. Different letters in the same column for each property indicate significant effects (at $p<0.05$ level) of soil sealing degree compared with the non-sealed sites

The activity of DHA, CAT, GLU, and CEL was not statistically differentiated between the control and sealed soils, as well as between the degree of soil sealing (Table 2). The NR and FDA activities were significantly higher in the A and C group of soils than at the impervious sites (B). Soil UR activity was the highest in the control soils, followed by the semipervious and impervious sites. Some enzyme activity data (DHA, CAT, GLU, and CEL) were very variable, which was confirmed by high SD and CV values. Soil UR and NR activities were moderately variable and characterized by a coefficient of variation (CV) of 16-35\%. 


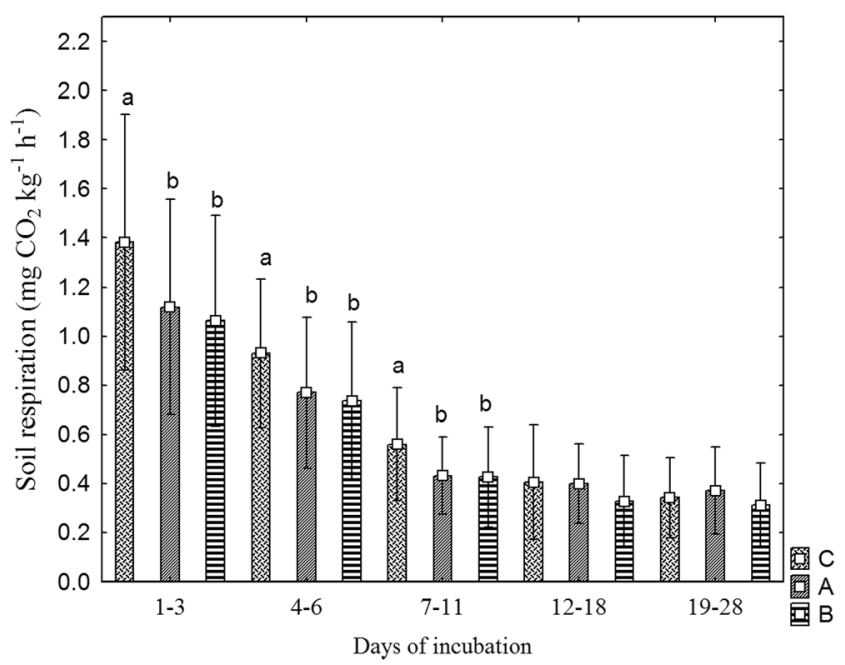

Fig. 4 Dynamics of accumulated $\mathrm{CO}_{2}$ emission of the studied soil samples (means $\pm \mathrm{SD}$ ). $C$ control (non-sealed soils), $A$ semi-pervious sites, $B$ impervious sites. Different letters within the same incubation period (e.g., 1-3 days) indicate significant effects (at $p<0.05$ level) of soil sealing compared with non-sealed sites. The lack of letters indicates the lack of significant differences

\subsection{Soil physicochemical properties}

The physical and chemical properties of the studied soils are presented in Table 4. Soil sealing significantly reduced the content of $\mathrm{C}_{\mathrm{ORG}}$ and $\mathrm{N}_{\text {TOT }}$ compared to non-sealed soils (C), while the degree of soil sealing did not result in any statistically significant changes (Tukey's test; $p<0.05$ ).

Table 3 Soil C:N ratio and soil microbial parameters as dependent on the degree of soil sealing

\begin{tabular}{llcc}
\hline Ratio & $\begin{array}{l}\text { Degree of } \\
\text { soil sealing }\end{array}$ & Mean $( \pm \mathrm{SD})$ & Range \\
\hline $\mathrm{C}_{\text {ORG }}: \mathrm{N}_{\text {TOT }}$ & $\mathrm{C}$ & $14.7(4.54) \mathrm{a}$ & $9.3-22.1$ \\
& $\mathrm{~A}$ & $14.1(3.84) \mathrm{a}$ & $9.1-21.1$ \\
& $\mathrm{~B}$ & $18.5(5.58) \mathrm{a}$ & $11.1-28.9$ \\
$\mathrm{MBC}: \mathrm{MBN}$ & $\mathrm{C}$ & $4.28(1.21) \mathrm{a}$ & $3.25-5.06$ \\
& $\mathrm{~A}$ & $4.16(1.03) \mathrm{a}$ & $3.44-4.94$ \\
& $\mathrm{~B}$ & $4.61(1.32) \mathrm{a}$ & $3.78-5.30$ \\
$\mathrm{MBC}: \mathrm{C}_{\text {ORG }}$ & $\mathrm{C}$ & $3.32(1.34) \mathrm{a}$ & $0.34-5.95$ \\
& $\mathrm{~A}$ & $2.01(1.13) \mathrm{b}$ & $0.25-5.34$ \\
& $\mathrm{~B}$ & $1.79(1.01) \mathrm{b}$ & $0.39-3.91$ \\
$\mathrm{MBN}: \mathrm{N}_{\mathrm{TOT}}$ & $\mathrm{C}$ & $5.88(2.56) \mathrm{a}$ & $1.46-7.00$ \\
& $\mathrm{~A}$ & $3.44(1.99) \mathrm{b}$ & $1.25-6.45$ \\
& $\mathrm{~B}$ & $3.68(1.56) \mathrm{b}$ & $1.26-4.29$ \\
$\mathrm{qCO} 2$ & $\mathrm{C}$ & $2.29(0.88) \mathrm{b}$ & $0.83-3.35$ \\
& $\mathrm{~A}$ & $2.18(1.01) \mathrm{b}$ & $0.81-3.27$ \\
& $\mathrm{~B}$ & $3.08(1.45) \mathrm{a}$ & $1.00-5.01$ \\
\hline
\end{tabular}

$q \mathrm{CO}_{2}$ metabolic quotient, $\mathrm{qCO}_{2}=\mathrm{mg} \mathrm{C}-\mathrm{CO}_{2}(\mathrm{gCmic})^{-1} \mathrm{~h}^{-1}$; different letters in the same column for each property indicate significant effects (at $p<0.05$ level) of soil sealing degree compared with the non-sealed sites
Soil organic carbon values ranged widely between 1.31 and $9.90 \mathrm{~g} \mathrm{~kg}^{-1}$, while the $\mathrm{N}_{\mathrm{TOT}}$ content varied between 0.024 and $0.72 \mathrm{~g} \mathrm{~kg}^{-1}$. The $\mathrm{C}: \mathrm{N}$ ratio, ranging widely from 9.3 to 28.9 , was not significantly differentiated between the control and sealed soil, or between both categories of soil sealing (Table 3). The highest water content was recorded in the control soils following the impervious and semi-pervious sites (Table 4). Soil water content was significantly correlated with the sum of precipitation ( $\mathrm{mm}$ ) that was measured between April and September 2012 in the control soils (C) and on the semi-pervious sites (A), while there was no such relationship between air temperature and soil moisture (Table 5). There was no significant variation in other physicochemical properties related to the degree of soil sealing and the control. The $\mathrm{pH}$ of control soils ranged from neutral to alkaline, while the reaction of semi-pervious sites was slightly acid to alkaline. The widest range of $\mathrm{pH}$ values was noted for impervious sites where reaction was acid to alkaline. Bulk density ranging from 1.27 to $1.75 \mathrm{~g} \mathrm{~cm}^{3}$ did not show considerable soil compaction and was close to natural (Table 4).

The raw data of physicochemical properties showed high differentiation among and within the studied groups of soils (C, A, and B), which was confirmed by SD and coefficients of variation (CV\%). Among the physicochemical properties studied, silt and clay as well as $\mathrm{P}_{\mathrm{AV}}$ content tended to be the most variable with a $\mathrm{CV}$ value of 57.8 $316.2 \%$. Similarly, $\mathrm{C}_{\mathrm{ORG}}, \mathrm{N}_{\mathrm{TOT}}$, and soil moisture showed high variability indicated by $\mathrm{CV}$ values above $36 \%$, which indicated that the results were quite differentiated in the studied area. Only the data of soil $\mathrm{pH}_{\mathrm{KCl}}$, bulk density, and the content of sand were distributed more homogeneously in the studied soils, which were reflected in $\mathrm{CV}$ values below $15 \%$ (Table 4).

\subsection{Relationship between soil microbial biomass, enzyme activities, and physicochemical properties}

The relationship between microbial biomass, enzyme activities $(M E)$, and soil physicochemical properties $(P C)$ was statistically analyzed with the canonical correlation analysis, and one pair of canonical variables (CVs) was extracted (Table 6).

The CVs of the group are given below:

$$
\begin{aligned}
M E_{1} & =1.753 X 1+1.672 X 2+0.417 X 3-0.674 X 4 \\
& +0.655 X 5-0.0161 X 6-0.0601 X 7+0.606 X 8 \\
& -0.704 X 9-0.243 X 10 \\
& \\
P C_{1}= & -0.485 Y 1-0.438 Y 2+0.023 Y 3+0.092 Y 4 \\
& +0.023 Y 5+0.682 Y 6+1.391 Y 7+0.097 Y \\
& +0.368 Y 9
\end{aligned}
$$


Table 4 Physicochemical properties as dependent on the degree of soil sealing

\begin{tabular}{|c|c|c|c|c|}
\hline Variable & $\begin{array}{l}\text { Degree of } \\
\text { soil sealing }\end{array}$ & Mean $( \pm \mathrm{SD})$ & Range & $\mathrm{CV}(\%)$ \\
\hline \multirow[t]{3}{*}{$\mathrm{C}_{\mathrm{ORG}}\left(\mathrm{g} \mathrm{kg}^{-1}\right)$} & $\mathrm{C}$ & $5.60(2.36) \mathrm{a}$ & $2.24-9.90$ & 57.8 \\
\hline & A & $2.22(1.81) b$ & $1.31-4.63$ & 61,8 \\
\hline & $\mathrm{B}$ & $2.79(1.67) b$ & $1.79-5.10$ & 39,9 \\
\hline \multirow[t]{3}{*}{$\mathrm{N}_{\text {TОТ }}\left(\mathrm{g} \mathrm{kg}^{-1}\right)$} & $\mathrm{C}$ & $0.36(0.17) \mathrm{a}$ & $0.13-0.72$ & 50.9 \\
\hline & A & $0.15(0.07) b$ & $0.064-0.30$ & 51.7 \\
\hline & $\mathrm{B}$ & $0.17(0.09) \mathrm{b}$ & $0.024-0.32$ & 45.6 \\
\hline \multirow[t]{3}{*}{$\mathrm{P}_{\mathrm{AV}}\left(\mathrm{mg} \mathrm{kg}^{-1}\right)$} & $\mathrm{C}$ & $200(138) \mathrm{a}$ & $50-456$ & 79.9 \\
\hline & A & $98(31) \mathrm{a}$ & $57-154$ & 57.8 \\
\hline & $\mathrm{B}$ & $180(127) \mathrm{a}$ & $47-460$ & 80.9 \\
\hline \multirow[t]{3}{*}{$\mathrm{pH}_{\mathrm{KCl}}$} & $\mathrm{C}$ & $7.57(0.6) \mathrm{a}$ & $6.68-8.30$ & 7.9 \\
\hline & $\mathrm{A}$ & $7.50(1.13) \mathrm{a}$ & $5.60-8.60$ & 15.1 \\
\hline & B & $7.57(1.15) \mathrm{a}$ & $4.60-8.40$ & 15.2 \\
\hline \multirow[t]{3}{*}{ Bulk density $\left(\mathrm{g} \mathrm{cm}^{3}\right)$} & $\mathrm{C}$ & $1.58(0.15) \mathrm{a}$ & $1.27-1.71$ & 9.4 \\
\hline & A & $1.64(0.09) \mathrm{a}$ & $1.52-1.75$ & 5.4 \\
\hline & $\mathrm{B}$ & $1.59(0.09) \mathrm{a}$ & $1.48-1.71$ & 5.5 \\
\hline \multirow[t]{3}{*}{ Sand $(\%)$} & $\mathrm{C}$ & $95.5(4.5) \mathrm{a}$ & $88-99$ & 4.7 \\
\hline & B & $97.4(3.4) \mathrm{a}$ & $91-100$ & 3.5 \\
\hline & A & $98.5(2.0) \mathrm{a}$ & $93-100$ & 2.0 \\
\hline \multirow[t]{3}{*}{ Silt (\%) } & $\mathrm{C}$ & $3.8(3.5) \mathrm{a}$ & $1-9$ & 91.8 \\
\hline & $\mathrm{B}$ & $2.3(2.7) \mathrm{a}$ & $0-7$ & 118.2 \\
\hline & A & $1.3(1.4) \mathrm{a}$ & $0-5$ & 109.1 \\
\hline \multirow[t]{3}{*}{ Clay (\%) } & $\mathrm{C}$ & $0.7(1.1) \mathrm{a}$ & $0-3$ & 151.3 \\
\hline & B & $0.4(0.7) \mathrm{a}$ & $0-2$ & 198.4 \\
\hline & A & $0.2(0.6) \mathrm{a}$ & $0-2$ & 316.2 \\
\hline \multirow[t]{3}{*}{ Water content $(\%)$} & $\mathrm{C}$ & 7.33 (4.36) a & $2.1-16.9$ & 60.0 \\
\hline & A & $5.75(2.60) b$ & $3.3-7.0$ & 45.1 \\
\hline & B & $4.75(1.14) \mathrm{c}$ & $1.8-11.2$ & 25.1 \\
\hline
\end{tabular}

$C$ control (non-sealed soils), $A$ semi-pervious sites, $B$ impervious sites, $C_{O R G}$ organic carbon content, $N_{T O T}$ total nitrogen content, $P_{A V}$ available phosphorus content; different letters in the same column for each property indicate significant effects (at $p<0.05 \mathrm{lev}$ el) of soil sealing degree compared with the non-sealed sites indicating their strong relationship (Table 6). The highest correlation was, however, between the moisture (Y9) and the first canonical variable for $M E$. Relatively low correlation ( $r=0.482$ and $r=0.344)$ was noted between $\mathrm{C}_{\mathrm{ORG}}$ and $\mathrm{N}_{\mathrm{TOT}}$ and the first canonical variable for $M E$. The highest correlation coefficients were noted between CEL, FDA, and the first canonical variable for $P C$ (Table 7). The redundancy analysis revealed that approximately $17.5 \%$ of the total variance in $M E$ was explained by the first canonical variable of $P C$.

A linear regression analysis was performed in order to confirm the positive relationship between water content and individual biological properties that were shown by a canonical correlation analysis, and some examples are presented in Fig. 5a-i. Positive correlations were found between water content and CAT, GLU activities and MBC content in the control soils (C) and on the semi-pervious sites (A) (except for GLU in the semi-pervious soils). However, no significant relationship was found between properties being studied in impervious sites (B).

In a hierarchical cluster analysis, the biological properties were grouped on the basis of their role in the transformation 
Table 6 Parameters of canonical correlation coefficients

\begin{tabular}{llllrrr}
\hline Canonical vector & Canonical $R$ & Canonical $R$ sqr & Lambda prime & Chi-square & $d f$ & $p$ \\
\hline 1 & 0.993685 & 0.987410 & 0.000004 & 137.5231 & 90 & $0.000961^{* * *}$ \\
2 & 0.979479 & 0.959379 & 0.000295 & 89.3997 & 72 \\
3 & 0.930439 & 0.865717 & 0.007272 & 54.1615 & 56 & 0.544769 \\
4 & 0.863652 & 0.745895 & 0.054152 & 32.0756 & 42 \\
5 & 0.720388 & 0.518959 & 0.213108 & 17.0055 & 30 & 0.865932 \\
6 & 0.604682 & 0.365640 & 0.443015 & 8.9557 & 20 & 0.983401 \\
7 & 0.465402 & 0.216599 & 0.698365 & 3.9491 & 12 & 0.984330 \\
8 & 0.315680 & 0.099654 & 0.891454 & 1.2639 & 6 & 0.973607 \\
9 & 0.099381 & 0.009877 & 0.990123 & 0.1092 & 2 \\
\hline
\end{tabular}

$d f$ degrees of freedom, $p$ probability of statistical significance; $* * * p<0.001$

processes of soil organic matter (Fig. 6). Generally, two clusters were obtained from the cluster analysis that was performed on the biological properties being studied. One included the MBC and MBN content, respiration activity, and all of the enzyme activities except for the FDA activity. The FDA activity was clearly clustered and was distant from the other properties. When the first cluster was analyzed in detail, three well-defined subclusters were visible. One group of properties is associated with $\mathrm{C}$ cycle in soil $\left(\mathrm{C}_{\mathrm{ORG}}, \mathrm{CEL}, \mathrm{GLU}\right.$, and $\mathrm{CAT}$ ). The second subcluster consists of the microbial biomass content and activity (MBC, MBN, and RESP), and the third subcluster includes enzymes involved in soil $\mathrm{N}$ transformation (NR and UR).

\section{Discussion}

The effects of sealing on the soil environment are reflected mainly in the disturbed exchange of water, gas, particles, and energy between the soil and other environmental compartments, which consequently affects the proper functioning of the soil (Kaye et al. 2006; Pickett and Candenasso 2008). In this study, significant decreases in some soil properties at impervious sites reflected the disturbance caused by soil sealing (Tables 2, 3, and 4; Fig. 4). Our results provided evidence that urban soil sealing can significantly decrease the content of carbon and nitrogen, both total and microbial as well as some enzymatic activities. It was consistent with previous studies on $\mathrm{C}$ storage in urban areas (Pouyat et al. 2006; Churkina et al. 2010), which had shown that the $\mathrm{C}$ concentration of urban soils covered by impervious surfaces is lower than that of open soils (urban grass and urban forest). These results were affected mainly by the vegetation, especially the accumulation of plant litter at the top soil layer of lawns and forest, which were selected mostly as control soils. Typically, plant-covered soils receiving frequent inputs of carbon substrates, nutrient, and water would maintain a healthy soil microbial community (Wang et al. 2011). As stated earlier, the reduced availability of carbon and substrates may be the main cause for the decreases in microbial biomass (Nannipieri and Eldor 2009). Nonetheless, a relatively low
Table 7 Canonical correlation between soil properties

\begin{tabular}{llll}
\hline $\begin{array}{l}\text { Correlation coefficients between microbial and } \\
\text { enzymatic properties and canonical variable of } \\
\text { soil physicochemical properties }\end{array}$ & $\begin{array}{l}\text { Correlation coefficients between soil physicochemical } \\
\text { properties and canonical variable of microbial and } \\
\text { enzymatic properties }\end{array}$ \\
\hline MBC $(X 1)$ & 0.047 & $\mathrm{C}_{\mathrm{ORG}}(Y 1)$ & 0.482 \\
MBN $(X 2)$ & $\mathrm{N}_{\mathrm{TOT}}(Y 2)$ & 0.344 \\
RESP $(X 3)$ & $\mathrm{pH}_{\mathrm{KCl}}(Y 3)$ & 0.381 \\
DHA $(X 4)$ & $\mathrm{P}_{\mathrm{AV}}(Y 4)$ & -0.111 \\
CAT $(X 5)$ & $\mathrm{Bulk}$ density $(Y 5)$ & 0.070 \\
UR $(X 6)$ & 0.017 & Sand $(Y 6)$ & -0.516 \\
NR $(X 7)$ & Silt $(Y 7)$ & 0.518 \\
GLU $(X 8)$ & 0.046 & Clay $(Y 8)$ & 0.513 \\
CEL $(X 9)$ & 0.391 & Moisture $(Y 9)$ & 0.734 \\
FDA $(X 10)$ & -0.313 & & \\
\end{tabular}


a) Water content $(\%)=4.3987+2.9582 \mathrm{CAT}$ Correlation: $r=0.816$

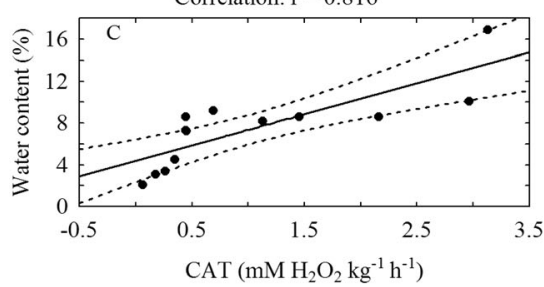

d) Water content $(\%)=3.8307+29.931 \mathrm{GLU}$ Correlation: $r=0.793$

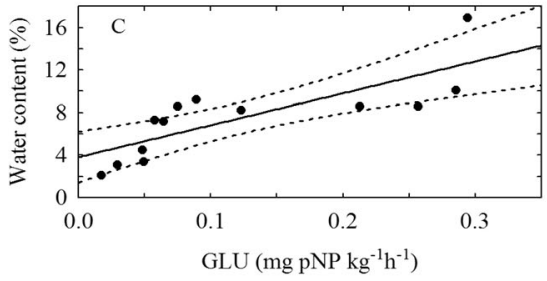

g) Water content $(\%)=2.5960+0.08004 \mathrm{MBC}$ Correlation: $r=0.718$

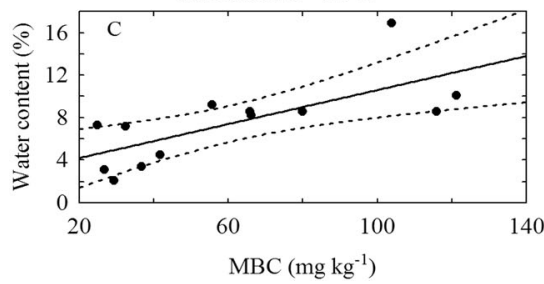

Fig. 5 Linear regression between water content (\%) and ( $a, b, c)$ CAT activity in non-sealed soils $(C)$, semi-pervious sites $(A)$, and impervious sites $(B) ;(d, e, f)$ GLU activity in non-sealed soils $(C)$, semi-pervious sites b) Water content $=3.6196+1.1725 \mathrm{CAT}$

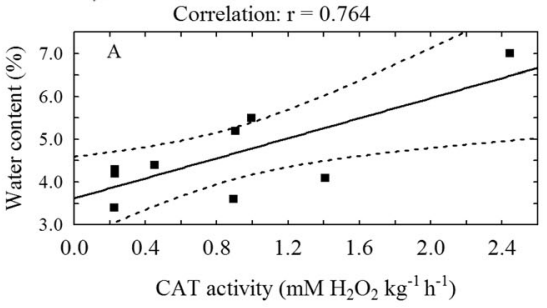

e) Water content (\%) $=3.9482+6.9642 \mathrm{GLU}$ Correlation: $\mathrm{r}=0.455$ (n.s.)

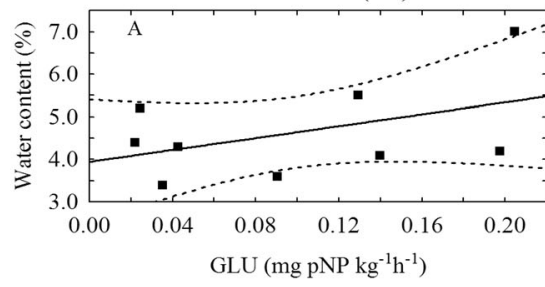

h) Water content $(\%)=3.0292+0.04422 \mathrm{MBC}$

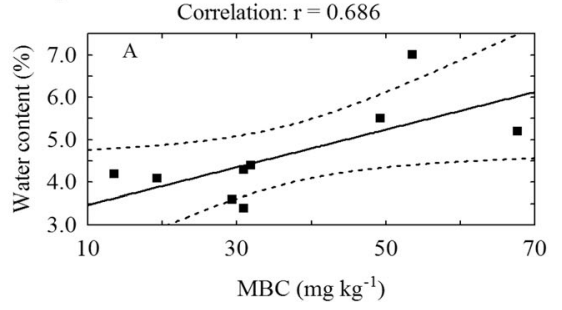

c) Water content $(\%)=4.5170+1.6123 \mathrm{CAT}$

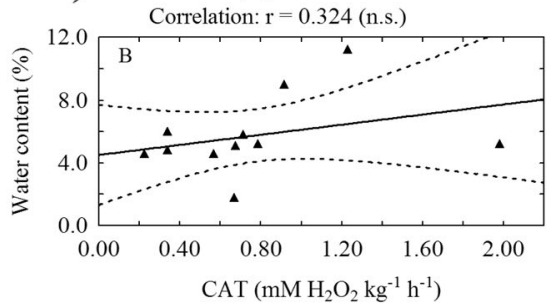

f) Water content $(\%)=5.0996+8.7276 \mathrm{GLU}$

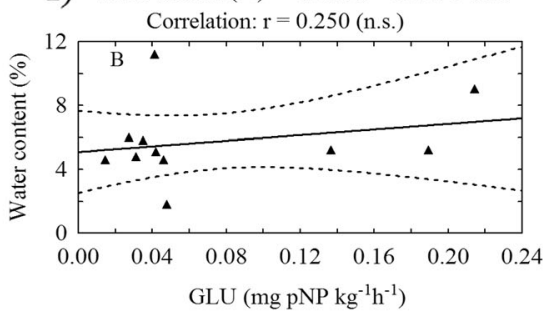

i) Water content (\%) $=4.4019+0.04288 \mathrm{MBC}$

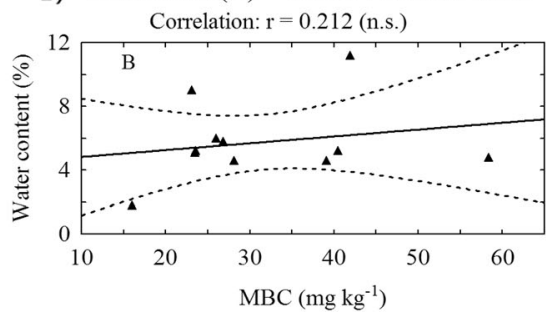

$(A)$, and impervious sites $(B) ;(g, h, i) \mathrm{MBC}$ content in non-sealed soils $(C)$, semi-pervious sites $(A)$, and impervious sites $(B) ; p<0.05$

correlation between $\mathrm{C}_{\mathrm{ORG}}$ and $\mathrm{N}_{\mathrm{TOT}}$ and the first canonical variable for $M E$ (Table 7) did not support the commonly known importance of these properties in the formation of microbial biomass content and activity (e.g., Piotrowska

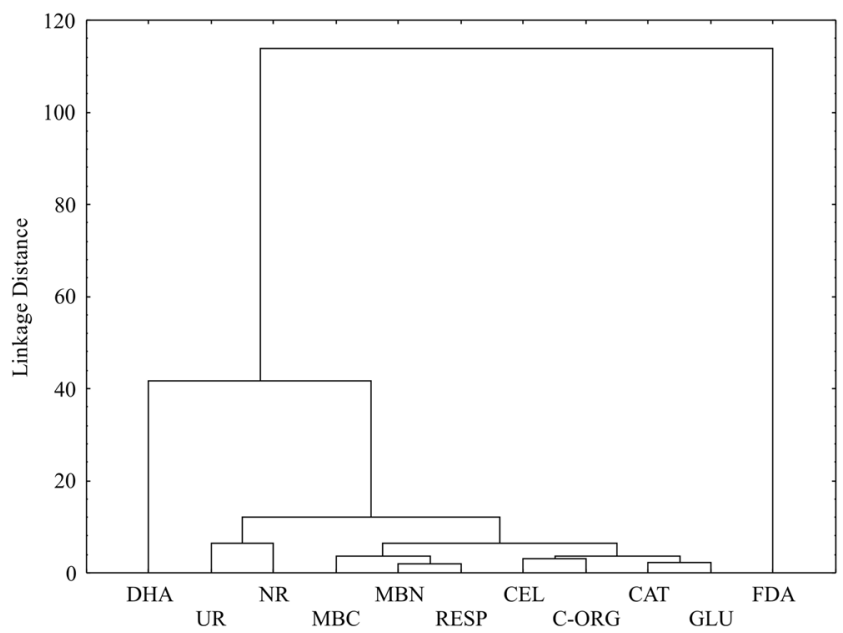

Fig. 6 Dendrogram derived from the hierarchical cluster analysis of soil properties et al. 2006; Gianfreda and Ruggiero 2006). In the course of infrastructure preparation, the topsoil is removed, which leads to reduction in the soil organic matter (Harris et al. 1999). Additionally, the impermeable materials make the supply of organic debris (e.g., tree leaves and other plant debris) impossible, and this can further reduce the input to the soil organic matter pool. Moreover, moisture stress, alkaline environment, and poor ventilation caused by sealing of soils may all contribute to the reduction in the microbial biomass content and activity (Tripathi and Singh 2009). In turn, destruction of vegetation and the alteration of soil nutrient status after soil sealing are the main factors affecting the synthesis and activities of soil enzymes (Chakrabarti et al. 2000).

The content of $\mathrm{CO}_{2}$ evolved during incubation which is an important factor of soil microbial activity. In this study, we showed that the accumulated $\mathrm{CO}_{2}$ emission from the control soils was higher than from the sealed soils, which indicates a decrease in the soil microbial activity. In accordance with Thomsen et al. (2008), our data showed that the content of C loss was higher in sealed soils than at open sites. The disturbance of sealed soils was additionally confirmed by significantly lower MBC: $\mathrm{C}_{\mathrm{ORG}}$ and $\mathrm{MBN}: \mathrm{N}_{\mathrm{TOT}}$ ratios as well as a 
higher metabolic quotient $\left(q \mathrm{CO}_{2}\right)$ compared with the control soils. In fact, the increasing $q \mathrm{CO}_{2}$ values confirmed the impact of site disturbance and organic matter losses (Insam and Haselwandter 1989).

In this study, the soil moisture was significantly reduced at semi-pervious and impervious sites compared with open soils (Table 4). A canonic correlation analysis showed a considerable effect of soil moisture on microbial biomass and enzymatic activity $(M E)$ (Table 7), which was confirmed by the analysis of regression that is presented in Fig. 5a-i. In fact, the sufficient water content in soil is one of the most important factors affecting the soil microbiological and enzymatic processes (Gianfreda and Ruggiero 2006). The impact of technogenic soil sealing on water movement was studied previously (Scalenghe and Ajmone Marsan 2009). The sealing of the soil surface makes it impermeable to water flow, and consequently the water regime of the underlying soils is severely altered. This not only reduces the soil moisture content but also lowers the water table in some urban areas, which in turn reduces the rate of chemical reaction (Scalenghe and Ajmone Marsan 2009). However, on some other sites, e.g., in Berlin, the water table rises (e.g., Wedewardt et al. 2003). The explanation for the changes in the depth of the groundwater table is the water balance, which depends on a reduced capillary rise and evapotranspiration, a shortened and reduced infiltration and an accelerated and increased surface runoff that is influenced by soil sealing (Wessolek 2008).

Many studies have reported high bulk densities in urban soils (e.g., Scharenbroch et al. 2005). In the study by Jim (1998), bulk density values exceeded $1.6 \mathrm{~g} \mathrm{~cm}^{-1}$, which is considered the upper threshold for unimpaired root growth (Mullins 1991). In this study, half of the soil samples had bulk density higher than $1.6 \mathrm{~g} \mathrm{~cm}^{3}$ (up to $1.75 \mathrm{~g} \mathrm{~cm}^{3}$ ), and there were no significant differences between control, semi-pervious, and impervious sites. This result indicated that soils selected as reference soils (mainly lawns, but also forest and roads without vegetation cover) had a similar degree of compactness as sealed soils due to various technogenic activities.

The soil in some urban areas is characterized by high heterogeneity with a very complex spatial variability (e.g., Lorenz and Lal 2009; Scalenghe and Ajmone Marsan 2009; Puskás and Farsang 2009; Wang et al. 2011), which was confirmed in our study (see ranges, SDs, and $\mathrm{CVs} \%$ for soil properties; Tables 2, 3, and 4). Many studies indicated highly variable concentration of organic $\mathrm{C}$, the total $\mathrm{N}$, and the $\mathrm{C}: \mathrm{N}$ ratio. For example, in urban soils of Halle (Germany), the concentration varied between 5 and $207 \mathrm{~g} \mathrm{C} \mathrm{kg}^{-1}$ (Machula et al. 2001) and the total $\mathrm{N}$ content ranged from 0.26 to $1.08 \mathrm{~g}$ $\mathrm{N} \mathrm{kg}^{-1}$ in Beijing (China) (Zhao et al. 2012) with the C:N ratio of 11.6-41.4. Urban soils do not always show a high degree of heterogeneity. When a large area of urban soils is covered by a uniform top soil, e.g., squares are covered by equal amounts of grass (lawns) or concrete (e.g., airports), the natural soil under these kinds of cover can be homogenous (e.g., Charzyński et al. 2013a). Although the data of almost all enzymes in this study showed clear differences between the control soils and sealed sites, only the activities of UR, NR, and FDA were statistically significantly affected (i.e., decreased) by soil sealing compared with controls. The lack of statistically significant differences in DHA, CAT, GLU, and CEL activities probably resulted from great dispersion of the data within each group of soil.

Generally, both physicochemical (except for soil moisture) and biological (except for NR) properties were not significantly different between soils representing different sealing categories (semi-permeable and impervious sites) even if the differences were considerable (e.g., MBN content, DHA, and CEL activities). Recently, it was suggested that permeable or semi-pervious pavement systems would help to limit the consequences of soil sealing to a certain extent (Zhao et al. 2012). Compared with impervious soil sealing, they seem to allow for at least exchange between the sealed soils and their environment, including gas exchange, water infiltration, and solute fluxes (Nehls et al. 2006). Disadvantages of semipermeable pavements could rely on the fact that with the increasing age, the original openings (wholes) inside the pavements become less conductive due to accumulations of different materials, such as foliage, dust, oil, etc. (Nehls et al. 2006). This fact could be the reason for the differences decreasing with time between semi- and non-impervious sites, like probably in the case of some properties in our study, including $\mathrm{MBC}, \mathrm{C}_{\mathrm{ORG}}$, and $\mathrm{N}_{\mathrm{TOT}}$ content.

\section{Conclusions}

The data of our study indicated that artificial sealing in urban areas can significantly alter the soil environment by deteriorating some biological and physicochemical properties. The content of soil carbon and nitrogen, both total and microbiological, as well as some enzymatic activities were significantly lower for sealed soil than for neighboring open sites. Additionally, the results of some properties (even if statistically nonsignificant) demonstrated that the impervious surfaces, generally more extensive and permanent as compared with semi-pervious surfaces, can result in reduction in soil moisture, microbial content, and activity (DHA, CEL, FDA, and $\mathrm{MBN}$ ) in urban soils. Thus, semi-impervious surface systems or other materials that allow the exchange of materials and energy between the soil and the atmosphere could reduce the negative effects of soil sealing in urban paved areas. The results clearly indicated the group of soil properties which occurred to be useful indicators of soil perturbation caused by artificial sealing $\left(\mathrm{C}_{\mathrm{ORG}}, \mathrm{N}_{\mathrm{TOT}}, \mathrm{MBC}, \mathrm{MBN}\right.$ content, $\mathrm{UR}, \mathrm{NR}$, FDA activities, and RESP rate) and should be taken into consideration in further studies of soil sealing. 
Acknowledgments The research was financed by the Polish Ministry of Science and Higher Education (project No. N N306 463738). Much gratitude is due to Ewa Kaźmierczak for proof reading the article.

Open Access This article is distributed under the terms of the Creative Commons Attribution License which permits any use, distribution, and reproduction in any medium, provided the original author(s) and the source are credited.

\section{References}

Adam G, Duncan H (2001) Development of a sensitive and rapid method for the measurement of total microbial activity using fluorescein diacetate (FDA) in a range of soils. Soil Biol Biochem 33:943-951

Ananyeva ND, Demkina TS, Jones WJ, Cabrera ML, Steen WC (1999) Microbial biomass in soils of Russia under long term management practices. Biol Fertil Soils 29:291-299

Anderson TH, Domsch KH (1990) Application of eco-physiological quotients $\left(\mathrm{qCO}_{2}\right.$ and $\left.\mathrm{qD}\right)$ on microbiological biomasses from soils of different cropping histories. Soil Biol Biochem 22:251-255

Berrueta LA, Alonso-Salces RM, Héberger K (2007) Supervised pattern recognition in food analysis. J Chromatogr A 1158:196-214

Bhaduri M, Minner M, Tatalovich S, Harbor J (2001) Long-term hydrologic impact of urbanization: a tale of two models. J Water Res Plan ASCE 127:13-19

Bremner JM, Mulvaney CS (1982) Nitrogen - total. In: Page AL, Miller RH, Keeny DR (eds) Methods of Soil Analysis, Part 2. American Society of Agronomy, Madison, pp 594-624

Brookes PC, Landman A, Pruden G, Jenkinson DS (1985) Chloroform fumigation and the release of soil nitrogen: a rapid extraction method to measure microbial biomass nitrogen in Soil. Soil Biol Biochem 17:837-842

Burghardt W (2006) Soil sealing and soil properties related to sealing. In: Frossard E, Blum WEH,Warkentin BP (eds) Function of soils for human societies and the environment, Special Publications 266, TheGeological Society, London, pp 117-124

Burt R (2004) Soil Survey laboratory methods manual. Soil Survey Investigations Report No. 42, version 4.0. USDA-NRCS, Lincoln, p 700

Chakrabarti K, Sarkar B, Chakraborty A, Banik P, Bagchi DK (2000) Organic recycling for soil quality conservation in a sub-tropical plateau region. J Agron Crop Sci 184:137-142

Charzyński P, Bednarek R, Błaszkiewicz J (2011) Morphology and properties of Ekranic Technosols in Torun and Cluj-Napoca. Soil Sci Ann 62(2):1-6 (in Polish)

Charzyński P, Bednarek R, Mendyk Ł, Świtoniak M, Pokojska-Burdziej A, Nowak A (2013a) Ekranosols of Toruń Airfield. In: Charzyński P, Hulisz P, Bednarek R (eds) Technogenic soils of Poland, 1st edn. Polish Society of Soil Science, Torun, pp 173-190

Charzyński P, Markiewicz M, Bednarek R, Mendyk Ł (2013b) Technogenic soils in Toruń. In: Charzyński P, Markiewicz M, Świtoniak M (eds) Technogenic soils atlas. Polish Society of Soil Science, Toruń, pp 111-140

Churkina G, Brown DG, Keoleian G (2010) Carbon stored in human settlements: the conterminous United States. Glob Chang Biol 16: $153-143$

Couch C, Petschel-Held G, Leontidou L (2007) Urban sprawl in Europe: landscape, land-use change and policy. Blackwell, London, p 275

EC (European Commission) (2006) Thematic Strategy for Soil protection. COM (2006) 231 final, 22.9.2006. EC, Brusels, EU, p 12

Eivazi F, Tabatabai MA (1988) Glucosidases and galactosidases in soils. Soil Biol Biochem 20:601-606
EEA (European Environment Agency) (2006) Urban Sprawl in Europe. The Ignored Challenge, EEA Report 10, Copenhagen, EU, p 60

EEA (European Environment Agency) (2010) Land in Europe: Prices, Taxes and Use Patterns. EEA Report 4, Copenhagen, EU, p 64

Gianfreda L, Ruggiero P (2006) Enzyme Activities in Soil. In: Nannipieri P, Smalla K (eds) Nucleic acids and proteins in soil. Springer, Berlin Heidelberg, pp 20-25

Harris RW, Clark JR, Matheny NP (1999) Arboriculture: integrated management of landscape trees, shrubs, and vines. Prentice-Hall, Englewood Cliffs

http://www.tutiempo.net/en/Climate /Poland/PL.html. Data reported by the weather station: 122500

Insam H, Haselwandter K (1989) Metabolic quotient of soil microflora to plant succession. Oecologia 79:174-178

IUSS Working Group WRB (2014) World Reference Base for Soil Resources 2014. International soil classification system for naming soils and creating legends for soil maps, World Soil Resources Reports, 106. FAO, Rome, p 181

Jim CY (1998) Impacts of intensive urbanization on trees in Hong Kong. Environ Conserv 25:146-159

Johnson JL, Temple KL (1964) Some variables affecting the measurement of "catalase activity" in soil. Soil Sci Soc Am J 28(2):207-209

Kandeler E (1995) Nitrate reductase activity. In: Schinner F, Ohlinger R, Kandeler E, Mergesin R (eds) Methods in soil biology. Springer Verlag, Berlin, pp 176-179

Kandeler E, Gerber H (1988) Short-term assay of soil urease activity using colorimetric determination of ammonia. Biol Fertil Soils 6:68-72

Karlen DL, Ditzler CA, Andrews SS (2003) Soil quality: why and how? Geoderma 114:145-156

Kaye JP, Burke IC, Mosier AR, Guerschman JP (2004) Methane and nitrous oxide fluxes from urban soils to the atmosphere. Ecol Appl 14:975-981

Kaye JP, Groffman PM, Grimm NB, Baker LA, Pouyat RV (2006) A distinct urban biogeochemistry? Trends Ecol Evol 21:192-199

Lorenz K, Kandeler E (2005) Biogeochemical characterization of urban soil profiles from Stuttgart, Germany. Soil Biol Biochem 37:13731385

Lorenz K, Lal R (2009) Biogeochemical C and N in urban soils. Environ Int 35:1-8

Machula G, Blume HP, Jahn R (2001) Discriminating factors of the spatial variability of soil quality parameters at landscape-scale. $\mathrm{J}$ Plant Nutr Soil Sci 164:547-554

Mullins CE (1991) Physical properties of soils in urban areas. In: Bullock P, Gregory PJ (eds) Soils in the urban environment. Blackwell Scientific Publications, Cambridge, pp 87-118

Nannipieri P, Eldor P (2009) The chemical and functional characterization of soil $\mathrm{N}$ and its abiotic components. Soil Biol Biochem 41: 2357-2369

Nehls T, Józeaciuk G, Sokołowska Z, Hajnos M, Wessolek G (2006) Pore-system characteristics of pavement seam materials of urban sites. J Plant Nutr Soil Sci 169:16-24

Nestroy O (2006) Soil sealing in Austria and its consequences. Ecohydrol Hydrobiol 6(1-4):171-173

Peffy T, Nawaz R (2008) An investigation into the extent and impacts of hard surfacing of domestic gardens in an area of Leeds, United Kingdom. Landsc Urban Plan 86:1-13

Pickett STA, Candenasso ML (2008) Altered resources, disturbance, and heterogeneity: a framework for comparing urban and non-urban soils. Urban Ecosyst 12(1):23-44

Piotrowska A, Iamarino G, Rao MA, Gianfreda L (2006) Short-term effects of olive mill waste water (OMW) on chemical and biochemical properties of a semiarid Mediterranean soil. Soil Biol Biochem 38:600-610

Pouyat RV, Yesilonis ID, Nowak DJ (2006) Carbon storage by urban soils in the United States. J Environ Qual 53:1566-1575

Puskás I, Farsang A (2009) Diagnostic indicators for characterizing urban soils of Szeged, Hungary. Geoderma 148:267-281 
Richard AJ, Dean WW (2002) Applied multivariate statistical analysis. Prentice-Hall, London, p 395

Salvati L, Perini L, Ceccarelli T, Zitti M, Bajocco S (2011) Towards a process-based evaluation of land vulnerability to degradation: a spatio-temporal approach in Italy. Ecol Indic 11(5):1216-1227

Savard J-P, Clergeau P, Mennechez G (2000) Biodiversity concepts and urban ecosystems. Landsc Urban Plan 48:131-142

Scalenghe R, Ajmone Marsan F (2009) The anthropogenic sealing of soil in urban areas. Landsc Urban Plan 90:1-10

Scharenbroch BC, Lloyd JE, Johnson ML (2005) Distinguishing urban soils with physical, chemical and biological properties. Pedobiologia 49:283-296

Schinner F, von Mersi W (1990) Xylanase-, CM-cellulase- and invertase activity in soil: an improved method. Soil Biol Biochem 22:511-515

Soil Survey Staff (2010) Keys to Soil Taxonomy, 11th edn. USDA Natural Resources Conservation Service, Washington, DC, p 346

Statistical Yearbook of Agriculture (2011) Central Statistical Office, Warsaw, p 393

Technical Report-2011-050 (2011) Final report: Overview of best practices for limiting soil sealing and mitigating its effects in EU-27. European Commission, EU, p 227

Thalmann A (1968) Zur Methodik derestimmung der Dehydrodgenaseaktivität in Boden mittels Triphenytetrazoliumchlorid (TTC). Landwirtsch Forsch 21:249-258

Thomsen IK, Kruse T, Bruun S, Kristiansen SM, Petersen SO, Jensen LS, Holst MK, Christensen BT (2008) Characteristics of soil carbon buried for 3300 years in a Bronze Age burial mound. Soil Sci Soc Am J 72:1292-1298
Tripathi N, Singh RS (2009) Influence of different land uses on soil nitrogen transformation after conversion from an Indian dry tropical forest. Catena 77:216-223

Vance ED, Brookes PC, Jenkinsen DS (1987) An extraction method for measuring soil microbial biomass C. Soil Biol Biochem 19:703-707

Wang M, Marked B, Shen W, Chen W, Peng C, Ouyang Z (2011) Microbial biomass carbon and enzyme activities of urban soils in Beijing. Environ Sci Pollut Res 18:958-967

Wedewardt M, Enge G, Kühne M (2003) Solution for large concentration sites in groundwater-saturated subsoils at the large infrastructure projects in Central Berlin. RMZ - Mater Geoenviron 50(1):413-416

Wei Z, Wu S, Zhou S, Lin C (2013) Installation of impervious surface in urban areas affects microbial biomass, activity (potential $\mathrm{C}$ mineralisation) and function diversity of the fine earth. Soil Res 51:59-67

Wessolek G (2008) Sealing of soils. In: Marzluff JM, Shulenberger E, Endlicher W, Alberti M, Bradley G, Ryan C, Simon U, ZumBrunnen C (eds) Urban Ecology An International Perspective on the Interaction Between Humans and Nature. Springer, pp 161-179

Wiegand J, Schott B (1999) The sealing of soils and its effect on soil-gas migration. Nuovo Cimeno Soc It Fisica C 22:449-455

Wilding LP (1985) Spatial variability: its documentation, accommodation, and implication to soil surveys. In: Nielsen DR, Bouma J (eds) Soil spatial variability. Pudoc, Wageningen, pp 166-194

Zhao D, Feng L, Wang R, Qingrui R (2012) Effect of soil sealing on the microbial biomass, $\mathrm{N}$ transformation and related enzymes activities at various depths of soils in urban area of Beijing, China. J Soils Sediments 12:519-539 